\title{
Simultaneous selection in beans for stability and high agronomic performance
}

\author{
N.D. Ribeiro ${ }^{1}$, C.R. Casagrande ${ }^{1}$, H.C. Mezzomo ${ }^{1}$, M.T.D.F. Possobom ${ }^{2}$, \\ S. de M. Steckling ${ }^{1}$ and G.R. Kläsener ${ }^{1}$ \\ ${ }^{1}$ Departamento de Fitotecnia, Universidade Federal de Santa Maria, Santa Maria, \\ RS, Brasil \\ ${ }^{2}$ Departamento de Fitotecnia, Universidade Federal de Viçosa, Viçosa, MG, \\ Brasil \\ Corresponding author: N.D. Ribeiro \\ E-mail: nerineia@hotmail.com / nerineia.ribeiro@gmail.com
}

Genet. Mol. Res. 15 (4): gmr15049095

Received August 23, 2016

Accepted October 4, 2016

Published November 21, 2016

DOI http://dx.doi.org/10.4238/gmr15049095

Copyright (C) 2016 The Authors. This is an open-access article distributed under the terms of the Creative Commons Attribution ShareAlike (CC BY-SA) 4.0 License.

\begin{abstract}
The objective of this study was to select common bean cultivars based on their stability for flowering, cycle, insertion of the first pod, grain yield, and high agronomic performance. Twenty experiments were carried out between 2000 and 2014, during two growing seasons, in Rio Grande do Sul, Brazil. The Eberhart and Russel, and Lin and Binns methods, as well as the additive main effect and multiplicative interaction (AMMI) method, were used to evaluate the stability of flowering, cycle, insertion of the first pod, and grain yield of 10 common cultivars in all experiments. The Eberhart and Russel, Lin and Binns, and AMMI methods identified the Carioca cultivar as the most stable for insertion of the first pod, and the Iraí cultivar as the most instable for flowering and cycle. The Pérola cultivar shows stability for flowering, cycle, and insertion of the first pod, and Guapo Brilhante is stable
\end{abstract}

Genetics and Molecular Research 15 (4): gmr15049095 
for grain yield, according to the Lin and Binns method. Controlled crossing between Pérola and Guapo Brilhante is recommended for the development of new common bean cultivars with greater stability for semi-early cycle, architecture of upright plant, and grain yield.

Key words: Phaseolus vulgaris; Flowering stability; Cycle stability; Plant architecture; Grain yield; Common bean cultivars

\section{INTRODUCTION}

Beans (Phaseolus vulgaris L.) are the most commonly used source of vegetal protein consumed in the countries of Eastern Africa and Latin America, representing 65\% of the daily intake of protein and 32\% of the energy intake (Blair et al., 2010). Within this context, increasing the grain yield of new common bean cultivars would offer a nutritional and affordable product to a large portion of the global population. However, the grain yield of common bean has dominant effects (Lima and Ramalho, 2016), suggesting difficulties in selection. Breeding programs for Brazilian black and carioca common bean have led to a reduction in the genetic diversity of agronomic traits (Cardoso et al., 2013). These results suggest that genetic gain for grain yield may be reduced in the future.

New common bean cultivars must have high agronomic performance to increase their production in order to be economically feasible. As such, it is important to develop early or semi-early cycle common bean cultivars, i.e., cycles of less than 84 days (Del Peloso et al., 2009), with upright plant architecture, and high-grain yield potential. These characters should also present low variation according to the growth environment, which may be evaluated by the phenotypical stability.

The stability of common bean grain yield has been extensively evaluated using the Eberhart and Russell (1966), Lin and Binns (1988), and additive main effect and multiplicative interaction (AMMI) methods (Carbonell et al., 2007; Melo et al., 2007; Pontes Júnior et al., 2012; Domingues et al., 2013; Silva et al., 2013; Pereira et al., 2009a,b, 2014; Barili et al., 2015a,b). Cycle stability in common bean has been studied using the Eberhart and Russell (1966) method, although few environments were considered (Ribeiro et al., 2004). There have been no similar reports in the literature on flowering and insertion of the first pod in common bean.

The selection of common bean cultivars with stability for flowering, cycle, insertion of the first pod, and grain yield is unprecedented in the literature. If a common bean cultivar is stable considering its flowering and cycle, this would permit better planning of sowing and harvesting times, thus avoiding periods of climatic stress. Common bean cultivars exhibiting insertion of the first pod higher than $12 \mathrm{~cm}$ are associated with an upright plant architecture (Melo, 2009). Therefore, using common bean cultivars with stability for characters that confer high agronomic performance would represent marketing advantages to common bean producers. There are no records in the literature of studies on common bean considering simultaneous selection for stability and high agronomic performance. Therefore, the objective of this study was to select common bean cultivars based on the stability of flowering, cycle, insertion of the first pod, and grain yield, as well as high agronomic performance.

Genetics and Molecular Research 15 (4): gmr15049095 


\section{MATERIAL AND METHODS}

\section{Growth conditions}

The experiments were conducted on a field area of the Department of Plant Sciences of Universidade Federal de Santa Maria, Santa Maria, State of Rio Grande do Sul, Brazil (latitude $29^{\circ} 42^{\prime} \mathrm{S}$, longitude $53^{\circ} 43^{\prime} \mathrm{W}$, and $95 \mathrm{~m}$ in altitude), from 2000 to 2014 in normal rainy and dry seasons, in a total of 20 environments. Experiments from the dry seasons of 2005, 2006, 2007, 2009, 2010, 2012, and 2013 were lost because of adverse climate conditions, particularity low temperatures close to the harvesting time.

The climate of the region is humid subtropical (Cfa) with warm summers and no definite dry season, according to the Köppen classification. The soil is classified as typical alitic Argisol (Hapludalf), and it was prepared in the conventional manner. The amount of fertilizer used was consistent with the needs determined by soil chemical analysis.

The experimental design consisted of randomized blocks, with three replicates. The plots consisted of four 4-m-long rows, $0.50 \mathrm{~m}$ apart, and a useful area of $3 \mathrm{~m}^{2}$, up to the normal rainy season of 2005. For the normal rainy season of 2006, the plots had two 4-m-long rows, $0.50 \mathrm{~m}$ apart, and a useful area of $4 \mathrm{~m}^{2}$. The number of evaluated cultivars differed depending on the year and growing season (Table 1), owing to the availability of seeds of new common bean cultivars included on the National Register of Cultivars, in the Ministry of Agriculture, Livestock and Supply for cultivation in Rio Grande do Sul.

Insects were controlled with the application of thiamethoxam and lambda-cyhalothrin, at a dose of $125 \mathrm{~mL} / \mathrm{ha}$, and weeds were mechanically eliminated whenever necessary, in order to prevent competition with the cultured crops. Fungicides were not applied to control disease.

\section{Data collection}

The characteristics evaluated in this experiment were: flowering, considering the period between emergence (V1) and the opening of the first flower (R6), and cycle, considering the interval between emergence (V1) and maturation (R9), i.e., when the pods lose their pigmentation and begin to dry, acquiring the typical coloration of each cultivar. Both characters were evaluated in the field, considering $51 \%$ of plants in the useful area at R6 and $\mathrm{R} 9$, respectively, in order to characterize flowering and cycle.

Insertion of the first pod was determined by the distance between the cotyledon node and insertion of the first pod, in centimeters, in 10 plants randomly collected from the useful area. The grain yield was determined by the extrapolation of product weight obtained from the useful area by hectare, at $13 \%$ average moisture.

\section{Statistical analysis}

The data were subjected to individual analysis of variance. The joint analysis of variance was carried out with data obtained for the 10 common cultivars in all environments (Carioca, Pérola, Diamante Negro, Guapo Brilhante, Guateian 6662, Macanudo, Macotaço, Minuano, Rio Tibagi, and Iraí). Those cultivars represent the most consumed grain types in Brazil: carioca (beige tegument with brown stripes: Carioca and Pérola), cranberry (creamcolored tegument with red stripes: Iraí), and black beans (other cultivars). The F test ( $\mathrm{P}$

Genetics and Molecular Research 15 (4): gmr15049095 
0.05) was used to evaluate the main effects (cultivars and environments) and the cultivar $\mathrm{x}$ environment interaction $(\mathrm{C} \times \mathrm{E})$, considering these fixed effects.

The homogeneity of the residual variance was verified by the Hartley maximum $\mathrm{F}$ test, using the criterion that the relationship between the highest and lowest residue mean square (QMr+/QMr-) must not exceed 7:1 (Cruz and Regazzi, 1997). Adaptability and stability analyses were carried out using the Eberhart and Russell (1966) method, the Lin and Binns (1988) modified method with Pi decomposition (Cruz and Carneiro, 2006), and the AMMI method (Zobel et al., 1988). Analyses were performed with the aid of Microsoft Office Excel, and GENES (Cruz, 2013) and R (R Development Core Team, 2012) software.

\section{RESULTS AND DISCUSSION}

\section{Individual analysis of variance of the cultivar}

A significant cultivar effect on flowering, cycle, insertion of the first pod, and grain yield was observed in most environments (Table 1). Therefore, there is genetic variability between the cultivars, and this allows the selection of characters that confer high agronomic performance in common bean.

In environments where the mean square of the cultivars was not significant for one or more of the evaluated characters, the F-test statistic $(\mathrm{Fc}<1.96)$ and heritability $\left(\mathrm{h}^{2}\right.$ $<49 \%$ ) values were low, conferring a moderate-to-low experimental accuracy, according to the classification shown by Cargnelutti Filho et al. (2009). In those cases, there was no differentiation among the common bean cultivars according to the $\mathrm{F}$ test.

Low variation coefficient values for flowering and cycle, varying from 1.19\% (cycle, 2003 rainy season) to $7.62 \%$ (flowering, 2008 rainy season) were obtained. For grain yield, the highest variation coefficient values ( 8.97 to $38.88 \%$ ) were observed, and the cultivar mean square was significant according to the $\mathrm{F}$ test $(\mathrm{P}<0.05)$ for all environments. Considering the current regulations of the National Register of Cultivars, Ministry of Agriculture, Livestock, and Supply, a variation coefficient of $\leq 25 \%$, or a significant F-test value for the cultivar regarding grain yield, all environments evaluated in this study could be used for the registration of common bean cultivars. However, the environment from the 2003 dry season was removed from the joint analysis of variance, since the variation coefficient value (38.88\%) was considered very high, according to the classification by de Oliveira et al. (2009), and the grain yield was very low $(267.06 \mathrm{~kg} / \mathrm{ha})$.

\section{Joint analysis of variance}

The relationship between the highest and the lowest residue mean square (QMr+/ QMr-) was lower than seven, which, according to Cruz and Regazzi (1997), indicates that the residual variances were homogeneous for flowering, cycle, insertion of the first pod, and grain yield. Therefore, it was possible to perform a joint analysis of variance for all characters. In this analysis, a significant difference $(\mathrm{P}<0.01)$ for the cultivar, environment, and $\mathrm{C} \times \mathrm{E}$ was observed for all characters (Table 2). Therefore, genetic variability exists for the selection of superior common bean cultivars in terms of the evaluated characters.

Genetics and Molecular Research 15 (4): gmr15049095 
The environments were different, and the performance of the common bean cultivars was not consistent throughout the years and growing seasons. A significant $\mathrm{C} \times \mathrm{E}$ interaction has previously been described for flowering (Mambrin et al., 2015), cycle (Pereira et al., 2012; Ribeiro et al., 2004, 2014), insertion of the first pod (Ribeiro et al., 2014; Maziero et al., 2015), and grain yield (Elias et al., 2007; Melo et al., 2007; Rocha et al., 2010; Pontes Júnior et al., 2012; Domingues et al., 2013; Silva et al., 2013; Pereira et al., 2009a,b, 2010, 2014; Barili et al., 2015a,b) in experiments evaluating the performance of common bean cultivars. The existence of a significant $\mathrm{C} \times \mathrm{E}$ interaction indicates that the stability analyses may be useful for the identification of superior cultivars.

\begin{tabular}{|c|c|c|c|c|c|c|c|c|c|c|c|}
\hline \multirow[t]{2}{*}{ Environment } & \multirow[t]{2}{*}{$\mathrm{N}$} & \multicolumn{5}{|c|}{ Flowering (days) } & \multicolumn{5}{|c|}{ Cycle (days) } \\
\hline & & CMS & Mean & $\mathrm{VC}$ & $\mathrm{Fc}$ & $\mathrm{h}^{2}$ & CMS & Mean & $\mathrm{VC}$ & $\mathrm{Fc}$ & $\mathrm{h}^{2}$ \\
\hline 1. Rainy 2000 & 16 & $11.31 *$ & 32.08 & 2.37 & 19.58 & 94.89 & $104.97 *$ & 72.71 & 3.01 & 21.86 & 95.43 \\
\hline 2. Dry 2001 & 16 & $33.22 *$ & 30.25 & 4.12 & 21.36 & 95.32 & $71.72 *$ & 72.77 & 2.20 & 27.99 & 96.43 \\
\hline 3. Rainy 2001 & 19 & $32.21 *$ & 34.93 & 4.24 & 14.67 & 93.18 & $12.55^{*}$ & 74.09 & 1.27 & 14.16 & 92.94 \\
\hline 4. Dry 2002 & 19 & $20.68^{*}$ & 31.02 & 4.61 & 10.09 & 90.09 & $57.65^{*}$ & 74.40 & 4.17 & 5.99 & 83.29 \\
\hline 5. Rainy 2002 & 19 & $24.70^{*}$ & 32.67 & 3.86 & 15.54 & 93.56 & $48.04^{*}$ & 74.89 & 1.80 & 26.36 & 96.21 \\
\hline 6. Dry 2003 & 19 & $26.66^{*}$ & 36.63 & 6.26 & 5.06 & 80.25 & $18.60^{*}$ & 80.54 & 2.04 & 6.90 & 85.52 \\
\hline 7. Rainy 2003 & 19 & $35.90^{*}$ & 38.12 & 2.25 & 48.78 & 97.95 & $18.05^{*}$ & 80.35 & 1.19 & 19.56 & 94.89 \\
\hline 8. Dry 2004 & 19 & $22.65^{*}$ & 32.74 & 4.04 & 12.96 & 92.28 & $77.16^{*}$ & 75.53 & 2.38 & 23.93 & 95.82 \\
\hline 9. Rainy 2004 & 18 & $8.10^{*}$ & 30.68 & 2.66 & 12.10 & 91.74 & $11.76^{*}$ & 67.57 & 1.48 & 11.73 & 91.48 \\
\hline 10. Rainy 2005 & 21 & $12.61 *$ & 32.79 & 2.32 & 21.83 & 95.42 & $10.05^{*}$ & 75.40 & 1.84 & 5.22 & 80.85 \\
\hline 11. Rainy 2006 & 19 & $22.68^{*}$ & 37.72 & 4.71 & 7.18 & 86.07 & $109.26^{*}$ & 82.89 & 2.50 & 25.33 & 96.05 \\
\hline 12. Rainy 2007 & 20 & $17.31 *$ & 39.55 & 2.79 & 14.20 & 92.96 & $3.66^{*}$ & 86.32 & 1.29 & 2.97 & 66.33 \\
\hline 13. Dry 2008 & 20 & $8.68^{*}$ & 31.85 & 2.36 & 15.37 & 93.49 & $15.06^{*}$ & 60.62 & 2.29 & 7.84 & 87.25 \\
\hline 14. Rainy 2008 & 18 & $11.68^{\mathrm{ns}}$ & 34.24 & 7.62 & 1.71 & 41.72 & $17.18^{*}$ & 81.33 & 1.75 & 8.44 & 88.15 \\
\hline 15. Rainy 2009 & 16 & $8.84^{\mathrm{ns}}$ & 38.21 & 6.70 & 1.35 & 25.78 & $48.04 *$ & 73.83 & 4.08 & 5.30 & 84.14 \\
\hline 16. Rainy 2010 & 26 & $5.15^{*}$ & 40.29 & 3.56 & 2.50 & 60.04 & $15.96^{*}$ & 79.72 & 2.03 & 6.08 & 83.55 \\
\hline 17. Dry 2011 & 26 & $6.33^{*}$ & 28.59 & 5.21 & 2.85 & 64.89 & $37.39^{*}$ & 88.82 & 2.41 & 8.18 & 87.77 \\
\hline 18. Rainy 2011 & 26 & $5.61^{*}$ & 30.41 & 4.91 & 2.51 & 60.24 & $15.11^{*}$ & 74.77 & 3.26 & 2.54 & 60.70 \\
\hline 19. Rainy 2012 & 26 & $13.21^{*}$ & 36.29 & 5.47 & 3.35 & 70.15 & $22.54^{*}$ & 72.74 & 3.07 & 4.51 & 77.85 \\
\hline \multirow[t]{3}{*}{ 20. Rainy 2013} & 26 & $5.53^{*}$ & 42.35 & 3.44 & 2.61 & 61.70 & $8.69^{\text {ns }}$ & 77.06 & 2.97 & 1.65 & 39.57 \\
\hline & & \multicolumn{5}{|c|}{ Insertion of the first pod $(\mathrm{cm})$} & \multicolumn{5}{|c|}{ Grain yield (kg/ha) } \\
\hline & & CMS & Mean & $\mathrm{VC}$ & $\mathrm{Fc}$ & $\mathrm{h}^{2}$ & CMS & Mean & $\mathrm{VC}$ & $\mathrm{Fc}$ & $\mathrm{h}^{2}$ \\
\hline 1. Rainy 2000 & 16 & $146.87^{*}$ & 12.60 & 24.56 & 15.34 & 93.48 & $505,130.81^{*}$ & 1863.18 & 16.31 & 5.47 & 81.72 \\
\hline 2. Dry 2001 & 16 & $83.49 *$ & 13.59 & 21.98 & 9.36 & 89.31 & $280,313.70^{*}$ & 916.22 & 22.56 & 6.56 & 84.75 \\
\hline 3. Rainy 2001 & 19 & $24.03 *$ & 14.93 & 19.86 & 2.73 & 63.43 & 961,814.73* & 2791.88 & 13.58 & 6.68 & 85.04 \\
\hline 4. Dry 2002 & 19 & $50.68^{*}$ & 9.63 & 32.26 & 5.25 & 80.94 & $179,132.92 *$ & 725.40 & 21.11 & 7.63 & 86.90 \\
\hline 5. Rainy 2002 & 19 & $49.04 *$ & 18.11 & 19.43 & 3.96 & 74.75 & $1,047,078.87^{*}$ & 1877.79 & 14.96 & 13.26 & 92.46 \\
\hline 6. Dry 2003 & 19 & $5.51^{\mathrm{ns}}$ & 12.63 & 14.15 & 1.72 & 42.02 & $24,407.24^{*}$ & 267.06 & 38.88 & 2.26 & 55.82 \\
\hline 7. Rainy 2003 & 19 & $12.67^{*}$ & 16.13 & 10.97 & 4.04 & 75.28 & $155,114.31^{*}$ & 2005.56 & 10.02 & 3.84 & 73.94 \\
\hline 8. Dry 2004 & 19 & $13.44^{*}$ & 16.02 & 14.71 & 2.42 & 58.67 & $111,672.48^{*}$ & 897.26 & 20.10 & 3.43 & 70.88 \\
\hline 9. Rainy 2004 & 18 & $46.53^{*}$ & 21.05 & 13.00 & 6.21 & 83.90 & $391,894.47^{*}$ & 1969.23 & 8.97 & 12.56 & 92.04 \\
\hline 10 . Rainy 2005 & 21 & $23.59 *$ & 21.18 & 13.32 & 2.96 & 66.26 & $476,603.50^{*}$ & 2370.06 & 13.50 & 4.65 & 78.52 \\
\hline 11. Rainy 2006 & 19 & $37.85^{*}$ & 22.71 & 11.89 & 5.19 & 80.74 & $771,799.18^{*}$ & 1343.26 & 17.66 & 13.71 & 92.70 \\
\hline 12. Rainy 2007 & 20 & $27.01 *$ & 19.33 & 12.77 & 4.43 & 77.43 & $327,383.51^{*}$ & 1202.31 & 26.57 & 3.21 & 68.83 \\
\hline 13. Dry 2008 & 20 & $4.63^{\mathrm{ns}}$ & 16.62 & 14.88 & 0.76 & 0.00 & $188,913.42 *$ & 2135.34 & 11.88 & 2.94 & 65.94 \\
\hline 14. Rainy 2008 & 18 & - & - & - & - & - & $69,995.94^{*}$ & 636.56 & 21.47 & 3.74 & 73.30 \\
\hline 15. Rainy 2009 & 16 & $5.89^{\mathrm{ns}}$ & 14.04 & 12.44 & 1.93 & 48.19 & $264,353.42 *$ & 789.98 & 24.69 & 6.95 & 85.61 \\
\hline 16. Rainy 2010 & 26 & $14.39 *$ & 15.71 & 11.09 & 4.74 & 78.91 & $434,458.81 *$ & 2447.73 & 10.36 & 6.75 & 85.19 \\
\hline 17. Dry 2011 & 26 & $8.50^{*}$ & 15.39 & 14.24 & 1.77 & 43.53 & $181,777.33^{*}$ & 1695.62 & 14.71 & 2.92 & 65.77 \\
\hline 18. Rainy 2011 & 26 & $9.77^{\mathrm{ns}}$ & 17.91 & 18.21 & 0.92 & 0.00 & $195,166.64^{*}$ & 1642.88 & 15.26 & 3.10 & 67.78 \\
\hline 19. Rainy 2012 & 26 & $82.46^{*}$ & 30.10 & 13.42 & 5.05 & 80.20 & $128,966.86^{*}$ & 815.04 & 20.94 & 4.43 & 77.42 \\
\hline 20. Rainy 2013 & 26 & $13.41^{*}$ & 16.71 & 15.99 & 1.88 & 46.76 & $394,720.63^{*}$ & 1047.83 & 28.74 & 4.35 & 77.03 \\
\hline
\end{tabular}

${ }^{\mathrm{n}}$ Non-significant. *Significant by the $\mathrm{F}$ test at 0.05 probability. 
Table 2. Joint analysis of variance containing the mean squares, degrees of freedom (DF), mean, and variation coefficient (VC, \%) for flowering (FLO, days), cycle (days), grain yield (YIELD, $\mathrm{kg} / \mathrm{ha}$ ), and insertion of the first pod (IFP, cm) of 10 common bean cultivars, assessed from 2000 to 2014.

\begin{tabular}{l|c|c|c|c|c|c}
\hline \multirow{2}{*}{ Sources of variation } & d.f. & \multicolumn{5}{|c}{ Mean square } \\
\cline { 3 - 7 } & & FLO & CYCLE & YIELD & DF & IFP \\
\hline Block/ Environment & 38 & 4.31 & 7.70 & $131,937.06$ & 36 & 11.15 \\
\hline Cultivar (C) & 9 & $228.98^{*}$ & $358.56^{*}$ & $1,971,837.54^{*}$ & 9 & $201.56^{*}$ \\
\hline Environment (E) & 18 & $469.58^{*}$ & $1191.58^{*}$ & $12,072,012.85^{*}$ & 17 & $514.24^{*}$ \\
\hline C x E & 162 & $7.54^{*}$ & $22.23^{*}$ & $284,597.12^{*}$ & 153 & $25.04^{*}$ \\
\hline Residue & 342 & 1.66 & 2.83 & $48,704.11$ & 324 & 6.35 \\
\hline Mean & & 34.21 & 75.54 & 1496.98 & & 16.84 \\
\hline VC (\%) & & 3.77 & 2.23 & 14.74 & & 14.97 \\
\hline
\end{tabular}

*Significant by the $\mathrm{F}$ test at 0.01 probability.

\section{Stability for flowering and cycle}

\section{Determination of regression coefficient and deviation}

The Carioca, Minuano, Guapo Brilhante, and Macanudo cultivars showed a regression coefficient similar to 1 unit $\left(\beta_{1 i}=1\right)$ and non-significant regression deviation $\left(\sigma_{d i}^{2}\right.$ $=0$ ) for flowering, according to the Eberhart and Russell (1966) method (Table 3). Those common bean cultivars exhibit general adaptation and stability for flowering, i.e., they show some predictability and high repeatability for flowering in the evaluated environments. The Diamante Negro cultivar was also stable for flowering. For the Macotaço, Pérola, and Rio Tibagi cultivars, a significant regression deviation $\left({ }^{1} 0\right)$ and $\mathrm{R}^{2}$ values higher than $80 \%$ were observed, characterizing a tolerable or acceptable predictability, according to Cruz and Regazzi (1997). In those cultivars, the number of flowering days only slightly changed during the different years and growing seasons. The identification of common bean cultivars with stability for flowering is important for planning the sowing time, and avoiding flowering during periods of high mean air temperature and rainfall.

Flowering is strongly correlated with cycle in common bean (Burrato et al., 2007; Faria et al., 2009); therefore, this has been used to characterize early cycles. Hence, it is expected that common bean cultivars with adaptation and stability for flowering also show stability for cycle. However, none of the evaluated common bean cultivars showed $\beta_{1 i}=$ 1 and $\sigma_{d i}^{2}=0$ for cycle, according to the Eberhart and Russell (1966) method. Preliminary results by Ribeiro et al. (2004) showed that this methodology was efficient at identifying common bean cultivars with general adaptation for cycle $\left(\beta_{1 i}=1\right)$. The differences observed may be justified by the larger number of environments and the lower number of common cultivars evaluated in this study.

All evaluated cultivars, except for Iraí, had a tolerable or acceptable predictability for cycle $\left(\sigma_{d i}^{2} \neq 0\right.$ and $\left.\mathrm{R}^{2}>80 \%\right)$, i.e., only a slight variation to the cycle occurred due to environmental variation. The Pérola, Diamante Negro, Rio Tibagi, Macotaço, Carioca, Guateian 6662, Guapo Brilhante, Minuano, and Macanudo cultivars have an indeterminate growth habit with short (type II) or long (type III) guides, and present a semi-early cycle, according to the classification of Del Peloso et al. (2009).

Genetics and Molecular Research 15 (4): gmr15049095 
Table 3. Mean, regression coefficient $\left(\beta_{1 i}\right)$, regression deviation $\left(\sigma_{d i}^{2}\right)$, and determination coefficient $\left(\mathrm{R}^{2}\right)$ for flowering, cycle, grain yield, and insertion of the first pod obtained by the Eberhart and Russell (1966) method for 10 common bean cultivars, assessed from 2000 to 2014.

\begin{tabular}{|c|c|c|c|c|c|c|c|c|c|}
\hline \multicolumn{5}{|c|}{ Flowering (days) } & \multicolumn{5}{|c|}{ Cycle (days) } \\
\hline $\mathrm{C}^{(1)}$ & Mean & $\beta_{1 i}^{(2)}$ & $\sigma_{d i}^{2}(3)$ & $\mathrm{R}^{2}(\%)$ & $\mathrm{C}$ & Mean & $\beta_{1 i}$ & $\sigma_{d i}^{2}$ & $\mathrm{R}^{2}(\%)$ \\
\hline 5 & 35.72 & $1.07^{*}$ & $2.04 *$ & 87.94 & 9 & 78.58 & $1.05^{*}$ & $7.50^{*}$ & 84.52 \\
\hline 9 & 35.56 & $0.95^{*}$ & $1.19^{*}$ & 89.59 & 1 & 77.65 & $0.97^{*}$ & $3.51^{*}$ & 89.93 \\
\hline 3 & 35.47 & $0.88 *$ & $2.71^{*}$ & 79.91 & 7 & 77.30 & $1.02 *$ & $1.00^{*}$ & 95.70 \\
\hline 7 & 35.33 & $0.90^{*}$ & $0.38^{*}$ & 93.49 & 5 & 76.58 & $1.05^{*}$ & $6.41^{*}$ & 86.32 \\
\hline 8 & 34.81 & $1.09^{\mathrm{ns}}$ & $-0.18^{\text {ns }}$ & 98.13 & 8 & 76.26 & $0.96^{*}$ & $3.18^{*}$ & 90.43 \\
\hline 1 & 34.70 & $0.98^{*}$ & $0.36^{\mathrm{ns}}$ & 94.55 & 3 & 76.02 & $1.01^{*}$ & $1.76^{*}$ & 94.07 \\
\hline 6 & 34.31 & $0.99^{\text {ns }}$ & $0.26^{\mathrm{ns}}$ & 95.18 & 2 & 74.82 & $1.10^{*}$ & $1.50^{*}$ & 95.46 \\
\hline 2 & 33.70 & $1.01^{\mathrm{ns}}$ & $0.12^{\mathrm{ns}}$ & 96.19 & 6 & 74.65 & $1.08^{*}$ & $2.63^{*}$ & 93.24 \\
\hline 4 & 33.54 & $0.99^{\mathrm{ns}}$ & $0.19^{\mathrm{ns}}$ & 95.60 & 4 & 73.86 & $0.98^{*}$ & $8.45^{*}$ & 81.16 \\
\hline 10 & 28.93 & $1.13^{*}$ & $10.40^{*}$ & 65.83 & 10 & 69.72 & $0.77^{*}$ & $21.94^{*}$ & 52.20 \\
\hline Mean & 34.21 & & & & & 75.54 & & & \\
\hline \multicolumn{5}{|c|}{ Insertion of the first pod $(\mathrm{cm})$} & \multicolumn{5}{|c|}{ Grain yield (kg/ha) } \\
\hline $\mathrm{C}$ & Mean & $\beta_{1 i}$ & $\sigma_{d i}^{2}$ & $\mathrm{R}^{2}(\%)$ & $\mathrm{C}$ & Mean & $\beta_{1 i}$ & $\sigma_{d i}^{2}$ & $\mathrm{R}^{2}(\%)$ \\
\hline 9 & 20.90 & $0.77 *$ & $13.57^{*}$ & 40.54 & 2 & 1817.59 & $1.17^{*}$ & $72,105.59^{*}$ & 86.87 \\
\hline 1 & 18.85 & $0.74^{*}$ & $8.12^{*}$ & 49.25 & 6 & 1737.93 & $1.12^{*}$ & $57,214.26^{*}$ & 87.90 \\
\hline 5 & 17.38 & $1.43^{*}$ & $6.20 *$ & 81.73 & 4 & 1630.97 & $1.06^{*}$ & $108,044.90 *$ & 79.47 \\
\hline 7 & 16.86 & $1.19^{\text {ns }}$ & $1.39^{\text {ns }}$ & 88.06 & 8 & 1507.35 & $1.16^{*}$ & $42,730.31^{*}$ & 90.76 \\
\hline 8 & 16.83 & $1.01^{\mathrm{ns}}$ & $1.14^{\mathrm{ns}}$ & 85.01 & 10 & 1460.32 & $0.86^{*}$ & $123,892.83^{*}$ & 69.19 \\
\hline 3 & 16.32 & $1.26^{*}$ & $7.29^{*}$ & 75.49 & 1 & 1434.84 & $0.97^{*}$ & $43,020.84 *$ & 87.07 \\
\hline 6 & 16.13 & $1.02^{\mathrm{ns}}$ & $0.64^{\mathrm{ns}}$ & 87.39 & 3 & 1423.89 & $1.06^{*}$ & $61,102.05^{*}$ & 86.13 \\
\hline 4 & 15.79 & $0.74^{*}$ & $2.27^{*}$ & 69.36 & 5 & 1386.09 & $0.81^{*}$ & $68,186.52^{*}$ & 76.80 \\
\hline 2 & 15.48 & $1.18^{*}$ & $1.54^{*}$ & 87.42 & 9 & 1385.56 & $0.95^{*}$ & $50,557.34^{*}$ & 85.30 \\
\hline 10 & 13.83 & $0.66^{*}$ & $4.97^{*}$ & 52.73 & 7 & 1185.24 & $0.83^{*}$ & $43,633.55^{*}$ & 83.02 \\
\hline Mean & 16.84 & & & & & 1496.98 & & & \\
\hline
\end{tabular}

${ }^{(1)}$ Common bean cultivars: 1 = Diamante Negro, 2 = Guapo Brilhante, $3=$ Guateian 6662,4 = Macanudo, $5=$ Macotaço, 6 = Minuano, 7 = Rio Tibagi, 8 = Carioca, 9 = Pérola, $10=$ Iraí. ${ }^{(2)} \mathrm{H}_{0}: \beta_{1 \mathrm{i}}=1 .{ }^{(3)} \mathrm{H}_{0}: \sigma_{d i}^{2}=0$. ${ }^{\text {ns Non- }}$ significant. *Significant by the $\mathrm{F}$ test at 0.05 probability.

\section{Stability by the Lin and Binns method}

According to the Lin and Binns (1988) method modified with Pi decomposition (Cruz and Carneiro, 2006), the Macotaço and Pérola cultivars are adapted to favorable environments $(<$ Pif) and the Rio Tibagi and Guateian 6662 cultivars are adapted to unfavorable environments ( $<\mathrm{Piu}$ ) (Table 4). The Macotaço, Pérola, and Rio Tibagi cultivars showed the lowest Pi values, and were, therefore, the most stable cultivars for flowering. For cycle, the cultivars that adapted to favorable environments were Pérola and Rio Tibagi; the cultivars that adapted to unfavorable environments were Pérola and Diamante Negro; and the stable cultivars were Pérola, Diamante Negro, and Rio Tibagi. The selection of common bean cultivars with stability for flowering and cycle, using the Lin and Binns (1988) method, as well as the modifications described by Cruz and Carneiro (2006), is unprecedented in the literature.

The Pérola and Rio Tibagi cultivars showed stability for flowering and cycle, according to the Lin and Binns (1988) method. These phenological stages varied only slightly throughout the years and growing seasons for the Pérola and Rio Tibagi cultivars. This allows some planning regarding the sowing and harvesting times, in order to avoid the flowering and harvesting during periods of climatic stress.

Genetics and Molecular Research 15 (4): gmr15049095 
Table 4. Mean, adaptability, and stability parameters obtained by the Lin and Binns (1988) method modified with $\mathrm{Pi}$ decomposition in a favorable $\left(\mathrm{P}_{\text {if }}\right)$ and unfavorable $\left(\mathrm{P}_{\text {iu }}\right)$ environment for 10 common bean cultivars, assessed from 2000 to 2014 .

\begin{tabular}{|c|c|c|c|c|c|c|c|c|c|}
\hline \multicolumn{5}{|c|}{ Flowering (days) } & \multicolumn{5}{|c|}{ Cycle (days) } \\
\hline $\mathrm{C}^{(1)}$ & Mean & Pi general & Pif & Piu & $\mathrm{C}$ & Mean & Pi general & Pif & Piu \\
\hline 5 & 35.72 & 1.41 & 0.69 & 1.93 & 9 & 78.58 & 1.80 & 0.42 & 2.61 \\
\hline 9 & 35.56 & 1.66 & 1.24 & 1.95 & 1 & 77.65 & 3.84 & 3.25 & 4.19 \\
\hline 3 & 35.47 & 2.26 & 3.01 & 1.72 & 7 & 77.30 & 5.97 & 1.74 & 8.44 \\
\hline 7 & 35.33 & 1.79 & 2.25 & 1.45 & 5 & 76.58 & 9.83 & 3.19 & 13.71 \\
\hline 8 & 34.81 & 2.62 & 1.89 & 3.14 & 8 & 76.26 & 9.45 & 8.28 & 10.13 \\
\hline 1 & 34.70 & 3.34 & 3.33 & 3.35 & 3 & 76.02 & 11.75 & 5.67 & 15.30 \\
\hline 6 & 34.32 & 3.86 & 4.43 & 3.45 & 2 & 74.82 & 16.31 & 6.23 & 22.19 \\
\hline 2 & 33.70 & 5.92 & 5.89 & 5.95 & 6 & 74.65 & 15.19 & 7.75 & 19.54 \\
\hline 4 & 33.54 & 6.27 & 5.51 & 6.82 & 4 & 73.86 & 23.51 & 22.83 & 23.91 \\
\hline 10 & 28.93 & 37.56 & 45.60 & 31.72 & 10 & 69.72 & 66.77 & 56.21 & 72.93 \\
\hline \multicolumn{5}{|c|}{ Insertion of the first pod $(\mathrm{cm})$} & \multicolumn{5}{|c|}{ Grain yield $(\mathrm{kg} / \mathrm{ha})$} \\
\hline $\mathrm{C}$ & Mean & Pi general & Pif & Piu & $\mathrm{C}$ & Mean & Pi general & Pif & Piu \\
\hline 9 & 20.90 & 3.18 & 6.69 & 0.94 & 2 & 1817.59 & $39,009.76$ & $20,481.23$ & $59,597.01$ \\
\hline 1 & 18.86 & 8.21 & 13.29 & 4.97 & 6 & 1737.93 & $69,616.64$ & $70,994.65$ & $68,085.52$ \\
\hline 5 & 17.38 & 25.46 & 8.14 & 36.48 & 4 & 1630.97 & $164,700.31$ & $133,310.98$ & $199,577.35$ \\
\hline 7 & 16.86 & 24.49 & 16.30 & 29.71 & 8 & 1507.35 & $176,883.18$ & $159,532.87$ & $196,161.31$ \\
\hline 8 & 16.83 & 21.57 & 24.48 & 19.72 & 10 & 1460.32 & $215,246.66$ & $284,854.45$ & $137,904.66$ \\
\hline 3 & 16.32 & 27.66 & 26.65 & 28.30 & 1 & 1434.84 & $235,189.76$ & $324,805.10$ & $135,617.17$ \\
\hline 6 & 16.13 & 27.94 & 24.80 & 29.93 & 3 & 1423.89 & $245,024.48$ & $214,678.40$ & $278,742.35$ \\
\hline 4 & 15.79 & 33.43 & 41.98 & 27.99 & 5 & 1386.09 & $319,158.64$ & $455,106.48$ & $168,105.49$ \\
\hline 2 & 15.48 & 33.23 & 26.88 & 37.28 & 9 & 1385.56 & $297,818.40$ & $406,078.72$ & $177,529.15$ \\
\hline 10 & 13.83 & 50.36 & 64.03 & 41.66 & 7 & 1185.24 & $446,157.70$ & $580,847.44$ & $296,502.43$ \\
\hline
\end{tabular}

${ }^{(1)}$ Common bean cultivars: 1 = Diamante Negro, 2 = Guapo Brilhante, 3 = Guateian $6662,4=$ Macanudo, $5=$ Macotaço, $6=$ Minuano, 7 = Rio Tibagi, $8=$ Carioca, $9=$ Pérola, $10=$ Iraí.

\section{AMMI method analysis}

According to the AMMI method, the first three principal components were significant $(\mathrm{P}<0.01)$ and, when added, they represented 83.34 and $77.56 \%$ of the $\mathrm{C} \times \mathrm{E}$ interaction sum of squares for flowering and cycle, respectively (Table 5). Therefore, the AMMI 3 model is adequate to explain the effects of the $\mathrm{C} x \mathrm{E}$ interaction. Since the graphical representation of the AMMI 3 model is difficult, due to the need to show a three-dimensional graph, we chose to present biplot graphs as suggested by Melo et al. (2007): AMMI 1 (mean x first principal component, IPCA 1) and AMMI 2 (IPCA 1 x second principal component, IPCA 2) (Figure 1).

For flowering, the Guapo Brilhante (C2), Minuano (C6), Diamante Negro (C1), Carioca (C8), and Macanudo (C4) cultivars were closer to the origin of the AMMI axis of interaction (AMMI 1) (Figure 1A). Therefore, they contributed the least to the $\mathrm{C} \times \mathrm{E}$ interaction, and were considered stable for flowering. The stability for flowering of the Carioca (C8), Macanudo (C4), and Guapo Brilhante (C2) cultivars was confirmed on the AMMI 2 biplot graph (IPCA $1 \times$ IPCA 2) (Figure 1B), indicating that, for those cultivars, flowering varied less in the growth environments.

Interpretation of the AMMI 1 biplot showed that the Guapo Brilhante (C2), Guateian 6662 (C3), and Minuano (C6) cultivars were stable for cycle (mean x IPCA 1) (Figure 1C). However, only the stability of the Guateian 6662 (C3) cultivar was confirmed on the AMMI 2 biplot graph (Figure 1D). The Guateian 6662 cultivar has a semi-early cycle (76 days) and phenotypical stability for cycle, i.e., it shows low variation for the duration of the period between the emergence and maturation of the plants. 
Table 5. Eigenvalue, sum of squares of the $\mathrm{C} x \mathrm{E}$ interaction/principal component ratio $\left(\mathrm{SS}_{\mathrm{CxE}} / \mathrm{PC}\right)$, and percentage of the accumulated ratio (accumulated) for each axis of the principal component (PC) obtained by the additive main effect and multiplicative interaction (AMMI) method for 10 common bean cultivars, assessed from 2000 to 2014 .

\begin{tabular}{|c|c|c|c|c|c|c|}
\hline & \multicolumn{3}{|c|}{ Flowering (days) } & \multicolumn{3}{|c|}{ Cycle (days) } \\
\hline PC & Eigenvalue & $\mathrm{SS}_{\mathrm{CxE}} / \mathrm{PC}(\%)$ & Accumulated (\%) & Eigenvalue & $\mathrm{SS}_{\mathrm{CxE}} / \mathrm{PC}(\%)$ & Accumulated (\%) \\
\hline 1 & 247.42 & 60.77 & 60.77 & 568.84 & 47.38 & 47.38 \\
\hline 2 & 54.82 & 13.46 & 74.23 & 225.93 & 18.82 & 66.20 \\
\hline 3 & 37.10 & 9.11 & 83.34 & 136.37 & 11.36 & 77.56 \\
\hline 4 & 26.15 & 6.42 & 89.76 & 125.07 & 10.42 & 87.98 \\
\hline 5 & 17.55 & 4.31 & 94.07 & 58.79 & 4.90 & 92.88 \\
\hline 6 & 10.71 & 2.63 & 96.70 & 32.92 & 2.74 & 95.62 \\
\hline 7 & 7.00 & 1.72 & 98.42 & 24.87 & 2.07 & 97.69 \\
\hline 8 & 5.12 & 1.26 & 99.68 & 22.98 & 1.91 & 99.60 \\
\hline \multirow[t]{2}{*}{9} & 1.29 & 0.32 & 100.00 & 4.82 & 0.40 & 100.00 \\
\hline & \multicolumn{3}{|c|}{ Insertion of the first pod $(\mathrm{cm})$} & \multicolumn{3}{|c|}{ Grain yield (kg/ha) } \\
\hline $\mathrm{PC}$ & Eigenvalue & $\mathrm{SS}_{\mathrm{CxE}} / \mathrm{PC}(\%)$ & Accumulated (\%) & Eigenvalue & $\mathrm{SS}_{\mathrm{CxE}} / \mathrm{PC}(\%)$ & Accumulated (\%) \\
\hline 1 & 514.55 & 40.29 & 40.29 & $4,737,316.60$ & 30.83 & 30.83 \\
\hline 2 & 323.30 & 25.31 & 65.60 & $4,213,920.00$ & 27.42 & 58.25 \\
\hline 3 & 186.42 & 14.60 & 80.20 & $2,206,492.40$ & 14.36 & 72.61 \\
\hline 4 & 77.01 & 6.03 & 86.23 & $1,442,150.20$ & 9.38 & 81.99 \\
\hline 5 & 71.26 & 5.58 & 91.81 & $1,077,294.30$ & 7.01 & 89.00 \\
\hline 6 & 44.82 & 3.51 & 95.32 & $724,169.60$ & 4.71 & 93.71 \\
\hline 7 & 33.45 & 2.62 & 97.94 & $468,414.90$ & 3.05 & 96.76 \\
\hline 8 & 15.57 & 1.22 & 99.16 & $337,060.60$ & 2.19 & 98.95 \\
\hline 9 & 10.73 & 0.84 & 100.00 & $161,426.10$ & 1.05 & 100.00 \\
\hline
\end{tabular}

The environments that contributed least to the $\mathrm{C} \times \mathrm{E}$ interaction on the AMMI 1 biplot graph were the 2002 (E5), 2003 (E7), and 2012 (E18) rainy seasons for flowering, and the 2001 (E3), 2005 (E9), and 2010 (E15) rainy seasons for cycle (Figures 1A and 1C). On the AMMI 2 biplot graph, it was possible to confirm the lowest contribution for the $\mathrm{C}$ x E interaction for the 2012 rainy season (E18) for flowering, and the 2001 rainy season (E3) for cycle (Figures 1B and 1D).

The methods used did not consistently identify common bean cultivars with stability for flowering and cycle. However, the three methods used to determine stability identified the Iraí cultivar as the most unstable for flowering and cycle (Tables 3 and 4, Figures 1A, 1B, 1C, and 1D). This cultivar has an early cycle (70 days) and determinate growth habit (type I). The type I common bean cultivars showed a shorter duration for flowering period and an earlier cycle than the type II and III cultivars. Therefore, type I cultivars are more affected by adverse factors, such as high mean air temperature and rainfall, and exhibit low predictability for the duration of these phenological stages. This represents the first report on the identification of unstable common bean cultivars for flowering and cycle.

\section{Stability for insertion of the first pod and grain yield}

For Rio Tibagi, Carioca, and Minuano cultivars, $\beta_{1 i}=1$ and $\sigma_{d i}^{2}=0$ estimates were obtained, characterizing the general adaptation and stability for insertion of the first pod, according to the Eberhart and Russell (1966) method (Table 3). The Macotaço and Guapo Brilhante cultivars exhibited tolerable or acceptable predictability $\left(\sigma_{d i}^{2} \neq 0\right.$ and $\left.\mathrm{R}^{2}>80 \%\right)$ for insertion of the first pod. Insertion of the first pod in Rio Tibagi, Carioca, Minuano, Macotaço, and Guapo Brilhante cultivars was greater than $12 \mathrm{~cm}$, which is related to the upright plant

Genetics and Molecular Research 15 (4): gmr15049095 
architecture of common beans (Melo, 2009). In addition, those cultivars showed greater predictability across the different years and growing seasons for this character. This is of high importance when considering that common bean plants exhibiting higher insertion of the first pod are adequate for manual and mechanical harvesting, and they usually have better-quality grains, due to the reduced contact between the pods and soil (Costa et al., 2008).
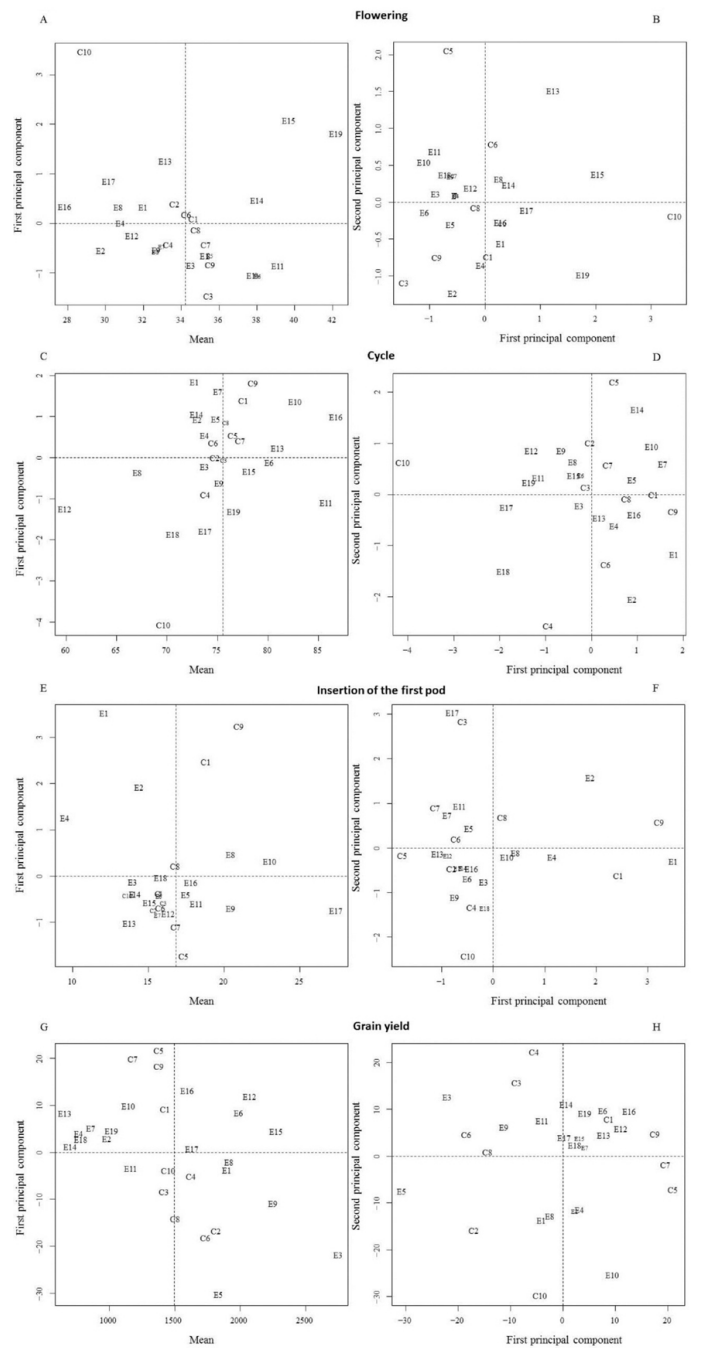

Figure 1. Biplot graph showing the characters flowering in days $(\mathbf{A}, \mathbf{B})$, cycle in days $(\mathbf{C}, \mathbf{D})$, insertion of the first pod in $\mathrm{cm}(\mathbf{E}, \mathbf{F})$, and grain yield in $\mathrm{kg} / \mathrm{ha}(\mathbf{G}, \mathbf{H})$ of 10 common bean cultivars, assessed from 2000 to 2014 . A, C, $\mathbf{E}$, and $\mathbf{G}$ show an AMM1 biplot graph (mean and first principal component), and $\mathbf{B}, \mathbf{D}, \mathbf{F}$, and $\mathbf{H}$ show an AMMI2 biplot graph (first and second principal component). Common bean cultivars: $\mathrm{C} 1=$ Diamante Negro, $\mathrm{C} 2=$ Guapo Brilhante, C3 = Guateian 6662, C4 = Macanudo, C5 = Macotaço, C6 = Minuano, C7 = Rio Tibagi, C8 = Carioca, C9 = Pérola, and C10 = Iraí. Evaluated environments: E1 = 2000 rainy, E2 = 2001 dry, E3 = 2001 rainy, E4 = 2002 dry, E5 = 2002 rainy, E6 = 2003 rainy, E7 = 2004 dry, E8 = 2004 rainy, E9 = 2005 rainy, E10 = 2006 rainy, E11 = 2007 rainy, $\mathrm{E} 12=2008$ dry, $\mathrm{E} 13=2008$ rainy, $\mathrm{E} 14=2009$ rainy, $\mathrm{E} 15=2010$ rainy, $\mathrm{E} 16=2011$ dry, $\mathrm{E} 17=2011$ rainy, $\mathrm{E} 18=2012$ rainy, and $\mathrm{E} 19=2013$ rainy.

Genetics and Molecular Research 15 (4): gmr15049095 
According to the Eberhart and Russell (1966) method, the Guapo Brilhante, Minuano, Macanudo, Carioca, and Guateian 6662 cultivars showed a specific adaptation to favorable environments $\left(\beta_{1 i}>1\right)$, and the other cultivars showed a specific adaptation to unfavorable environments $\left(\beta_{1 i}<1\right)$ for grain yield. None of the cultivars showed general adaptation and stability for grain yield for all evaluated environments. However, considering the significant estimates for regression deviations, and $\mathrm{R}^{2}$ values higher than $80 \%$, it was possible to identify cultivars with a higher predictability that grain yield vary less in the different environments: Guapo Brilhante, Minuano, Carioca, Diamante Negro, Guateian 6662, Pérola, and Rio Tibagi.

It was not possible to select common bean cultivars with a simultaneous high grain yield, regression coefficient equal to 1 unit (broad adaptability), and regression deviation equal to zero (high stability), which is considered ideal according to the criteria described by Eberhart and Russell (1966). Similarly, Oliveira et al. (2006) and Domingues et al. (2013) observed that this method was not efficient at selecting common bean cultivars with stability for grain yield. These results are not consistent with those previously reported by Burrato et al. (2007), Faria et al. (2009), and Barili et al. (2015a,b) using this methodology for common beans. This is justified because the Eberhart and Russell (1966) method is only efficient at identifying ideal cultivars when the data are adjusted to the linear model, i.e., with lower deviation values and regression coefficients close or equal to $1\left(\beta_{1 i}=1\right.$ and $\left.\sigma_{d i}^{2}=0\right)$, which was not observed in the present study or in those by Oliveira et al. (2006) and Domingues et al. (2013).

The Lin and Binns (1988) method modified with Pi decomposition (Cruz and Carneiro, 2006) was also used to select common bean cultivars with stability for insertion of the first pod and grain yield (Table 4). For the insertion of the first pod, it was possible to identify common bean cultivars with adaptation to favorable environments (Pérola, Macotaço, and Diamante Negro), to unfavorable environments (Pérola, Diamante Negro, and Carioca), and stable cultivars (Pérola, Diamante Negro, and Carioca). No previous studies were identified in the literature that evaluated stability for insertion of the first pod in common beans, using this methodology.

In relation to the grain yield, Guapo Brilhante and Minuano cultivars showed the lowest Pif and Piu values among the evaluated cultivars, i.e., they can be adapted to favorable and unfavorable environments. Guapo Brilhante, Minuano, and Macanudo were the most stable cultivars $(<\mathrm{Pi})$ and those with the highest mean values for grain yield. Cultivars with a lower Pi value, identified according to the Lin and Binns (1988) method, are desirable, since they indicate lower deviations in relation to the maximal grain yield of each environment, i.e., their performance was close to the maximum in most environments. This method has been broadly used to identify common bean cultivars with stability for grain yield, since it is easy to analyze and interpret the results (Carbonell et al., 2007; Melo et al., 2007; Pereira et al., 2009a, 2009b; Pontes Júnior et al., 2012; Domingues et al., 2013; Silva et al., 2013).

The first three principal components were significant $(\mathrm{P}<0.01)$ according to the AMMI analysis and, when added, they referred to 80.20 and $72.61 \%$ of the sum of squares of the $\mathrm{Cx}$ E interaction for the insertion of the first pod and grain yield, respectively (Table 5). These values were higher than those described for the stability of grain yield in common beans, evaluated using the AMMI method (Melo et al., 2007; Pereira et al., 2009a,b, 2014).

For the insertion of the first pod, the Carioca (C8), Guateian 6662 (C3), and Macanudo (C4) cultivars were closer to the origin of the AMMI axis of interaction (AMMI 1); therefore, they contributed the least to the $\mathrm{Cx}$ E interaction, and were stable for insertion of the first pod (Figure 1E). On the AMMI 2 biplot graph, only the stability of the Carioca (C8) cultivar was 
confirmed (Figure 1F). The Pérola cultivar was the most unstable for insertion of the first pod (Figures $1 \mathrm{E}$ and $1 \mathrm{~F}$ ), which is not desirable, since the plant may have an upright or decumbent architecture, depending on the growth conditions.

The Macanudo (C4), Iraí (C10), and Diamante Negro (C1) cultivars were stable for grain yield, according to the AMMI 1 biplot graph (Figure $1 \mathrm{G}$ ). According to the AMMI 2 biplot graph, only the Diamante Negro (C1) cultivar showed stability (Figure $1 \mathrm{H})$. The Diamante Negro cultivar was stable for grain yield on both biplots; however, it was ranked sixth for grain yield (Table 3). Similarly, Domingues et al. (2013) and Pereira et al. (2014) observed that not all stable lines, identified by the AMMI method, were those with higher grain yields.

The following environments presented lower contribution for the $\mathrm{C} \times \mathrm{E}$ interaction on both biplot graphs: the 2011 dry season (E16) for insertion of the first pod, and the 2011 rainy season (E17) for grain yield (Figures $1 \mathrm{E}, 1 \mathrm{~F}, 1 \mathrm{G}$, and $1 \mathrm{H}$ ). In the 2001 rainy season (E3), the highest value for grain yield was obtained $(2791.88 \mathrm{~kg} / \mathrm{ha})$ and, in the 2008 rainy season (E13), the lowest values were obtained $(636.56 \mathrm{~kg} / \mathrm{ha})$, providing examples of a favorable and unfavorable environment, respectively. The experiments contrasted, although they were conducted over several years, in the same location, and during traditional growing seasons. The differences between years and growing seasons are more important than those across growth locations, according to Torga et al. (2013).

The methods used were consistent in their identification of the Carioca cultivar for stability of insertion of the first pod. This cultivar ranked fifth in terms of greatest insertion of the first pod, among the evaluated cultivars. However, the methodologies were not consistent in their identification of common bean cultivars stable for grain yield. This is justified by the fact that the Eberhart and Russell (1966), Lin and Binns (1988), and AMMI methods provide complementary information (Melo et al., 2007).

Simultaneous selection for stability and high agronomic performance is not an easy task in common beans, due to the difficulty of identifying a stable cultivar with all favorable characters for selection. This was not possible in the present study, even when utilizing three stability methodologies used widely in studies of common bean. However, Pérola cultivar showed stability for flowering, cycle, and insertion of the first pod, and Guapo Brilhante cultivar was the most stable for grain yield, according to the Lin and Binns (1988) method. This method identified, among the most stable cultivars, those with the highest values for the favorable characters for selection. Controlled crosses between Pérola and Guapo Brilhante are recommended for the development of new common bean cultivars with greater stability for semi-early cycle, architecture of upright plants, and grain yield.

\section{Conflicts of interest}

The authors declare no conflict of interest.

\section{ACKNOWLEDGMENTS}

We would like to thank Conselho Nacional de Desenvolvimento Científico e Tecnológico $(\mathrm{CNPq})$ for the financial aid and scholarships granted. We would also like to thank Fundação de Amparo à Pesquisa do Estado de Minas Gerais (FAPEMIG) for the grants awarded.

Genetics and Molecular Research 15 (4): gmr15049095 


\section{REFERENCES}

Barili LD, do Vale NM, do Prado AL, Carneiro JE de S, et al. (2015a). Genotype-environment interaction in common bean cultivars with carioca grain cultivated in Brazil in the last 40 years. Crop Breed. Appl. Biotechnol. 15: 244-250. http:// dx.doi.org/10.1590/1984-70332015v15n4a41

Barili LD, do Vale NM, Amaral R de C, Carneiro JE de S, et al. (2015b). Adaptabilidade e estabilidade e a produtividade de grãos em cultivares de feijão preto recomendadas no Brasil nas últimas cinco décadas. Cienc. Rural 45: 19801986. http://dx.doi.org/10.1590/0103-8478cr20141383

Blair MW, González LF, Kimani PM and Butare L (2010). Genetic diversity, inter-gene pool introgression and nutritional quality of common beans (Phaseolus vulgaris L.) from Central Africa. Theor. Appl. Genet. 121: 237-248. http:// dx.doi.org/10.1007/s00122-010-1305-x

Burrato JS, Moda-Cirino V, Fonseca Júnior NS, Prete CEC, et al. (2007). Adaptabilidade e estabilidade produtiva em genótipos precoces de feijão no estado do Paraná. Semin. Cienc. Agrar. 28: 373-380. http://dx.doi.org/10.5433/1679$0359.2007 \mathrm{v} 28 \mathrm{n} 3 \mathrm{p} 373$

Carbonell SAM, Chiorato AF, de Resende MDV, Dias LA dos S, et al. (2007). Estabilidade de cultivares e linhagens de feijoeiro em diferentes ambientes no estado de São Paulo. Bragantia 66: 193-201. http://dx.doi.org/10.1590/S0006$\underline{87052007000200003}$

Cardoso PCB, Veiga MM, de Menezes IP, Valdisser PAMR, et al. (2013). Molecular characterization of high performance inbred lines of Brazilian common beans. Genet. Mol. Res. 12: 5467-5484.http://dx.doi.org/10.4238/2013.February.6.4

Cargnelutti Filho A, Storck L and Ribeiro ND (2009). Medidas da precisão experimental em ensaios com genótipos de feijão e de soja. Pesq. Agropec. Bras. 44: 1225-1231.

Cruz CD (2013). GENES - a software package for analysis in experimental statistics and quantitative genetics. Acta Sci. Agron. 35: 271-276. http://dx.doi.org/10.4025/actasciagron.v35i3.21251

Cruz CD and Regazzi AJ (1997). Modelos biométricos aplicados ao melhoramento genético. Universidade Federal de Viçosa, Viçosa.

Cruz CD and Carneiro PCS (2006). Modelos biométricos aplicados ao melhoramento genético, 2nd edn. Universidade Federal de Viçosa, Viçosa.

Costa JG de C, Rava CA, Zimmermann FJP and Melo LC (2008). Yield stability and adaptability of common bean lines developed by EMBRAPA. Pesq. Agropec. Trop. 38: 141-145.

de Oliveira RL, Muniz JA, de Andrade MJB and dos Reis RL (2009). Precisão experimental em ensaios com a cultura do feijão. Cienc. Agrotec. 33: 113-119. http://dx.doi.org/10.1590/S1413-70542009000100016

Del Peloso MJ, Melo LC, Pereira HS, de Faria LC, et al. (2009). Cultivares de feijoeiro comum desenvolvidas pela Embrapa. In: Feijão: tópicos especiais de manejo (Fanceli AL, ed.). 2nd edn. Escola Superior de Agricultura Luiz de Queiróz, Piracicaba, 23-40.

Domingues L da S, Ribeiro ND, Minetto C, de Souza JF, et al. (2013). Metodologias de análise de adaptabilidade e de estabilidade para a identificação de linhagens de feijão promissoras para o cultivo no Rio Grande do Sul. Semin. Cienc. Agrar. 34: 1065-1076. http://dx.doi.org/10.5433/1679-0359.2013v34n3p1065

Eberhart SA and Russell WA (1966). Stability parameters for comparing varieties. Crop Sci. 6: 36-40. http://dx.doi. org/10.2135/cropsci1966.0011183X000600010011x

Elias HT, Backes RL, Vidigal MCG, Balbinot Júnior AA, et al. (2007). Estabilidade e adaptabilidade de linhagens e cultivares de feijão do grupo carioca. Sci. Agraria. 8: 379-384. http://dx.doi.org/10.5380/rsa.v8i4.9883

Faria AP, Moda-Cirino V, Burrato JS, da Silva CFB, et al. (2009). Interação genótipo x ambiente na produtividade de grãos de linhagens e cultivares de feijão. Acta Sci. Agron. 31: 579-585.

Lima JG and Ramalho MAP (2016). Geometry applied to breeding common beans (Phaseolus vulgaris). Genet. Mol. Res. 15: 1-8. http://dx.doi.org/10.4238/gmr.15027873

Lin CS and Binns MR (1988). A superiority measure of cultivar performance for cultivar x location data. Can. J. Plant Sci. 68: 193-198. http://dx.doi.org/10.4141/cjps88-018

Mambrin RB, Ribeiro ND, Storck L, Domingues L da S, et al. (2015). Seleção de linhagens de feijão (Phaseolus vulgaris L.) baseada em caracteres morfológicos, fenológicos e de produção. Rev. Agric. 90: 141-155.

Maziero SM, Ribeiro ND and Storck L (2015). Simultaneous selection in beans for architecture, grain yield and minerals concentration. Euphytica 205: 369-380. http://dx.doi.org/10.1007/s10681-015-1392-5

Melo LC (2009). Procedimentos para condução de experimentos de valor de cultivo e uso em feijoeiro comum. EmbrapaCNPAF, Santo Antônio de Goiás.

Melo LC, Melo PGS, de Faria LC, Diaz JLC, et al. (2007). Interação com ambientes e estabilidade de genótipos de feijoeiro-comum na Região Centro-Sul do Brasil. Pesq. Agropec. Bras. 42: 715-723. http://dx.doi.org/10.1590/ $\underline{\text { S0100-204X2007000500015 }}$

Genetics and Molecular Research 15 (4): gmr15049095 
Oliveira GV, Carneiro PCS, Carneiro JE de S and Cruz CD (2006). Adaptabilidade e estabilidade de linhagens de feijão comum em Minas Gerais. Pesq. Agropec. Bras. 41: 257-265. http://dx.doi.org/10.1590/S0100-204X2006000200010

Pereira HS, Melo LC, de Faria LC, Diaz JLC, et al. (2009a). Stability and adaptability of carioca common bean genotypes in states of the central South Region of Brazil. Crop Breed. Appl. Biotechnol. 9: 181-188. http://dx.doi. org/10.12702/1984-7033.v09n02a11

Pereira HS, Melo LC, de Faria LC, Del Peloso MJ, et al. (2009b). Adaptabilidade e estabilidade de genótipos de feijoeiro-comum com grãos tipo carioca na Região Central do Brasil. Pesq. Agropec. Bras. 44: 29-37. http://dx.doi. org/10.1590/S0100-204X2009000100005

Pereira HS, Melo LC, de Faria LC, Del Peloso MJ, et al. (2010). Indicação de cultivares de feijoeiro-comum baseada na avaliação conjunta de diferentes épocas de semeadura. Pesq. Agropec. Bras. 45: 571-578.

Pereira HS, de Almeida VM, Melo LC, Wendland A, et al. (2012). Influência do ambiente em cultivares de feijoeiro-comum em cerrado com baixa altitude. Bragantia 71: 165-172. http://dx.doi.org/10.1590/S0006-87052012005000024

Pereira HS, Bueno LG, Del Peloso MJ, Abreu A de FB, et al. (2014). Agronomic performance and stability of andean common bean lines with white grains in Brazil. Bragantia 73: 130-137. http://dx.doi.org/10.1590/brag.2014.020

Pontes Júnior V de A, Melo LC, Pereira HS, Del Peloso MJ, et al. (2012). Productive potential and interaction of elite bean lines with environments in the Central Cerrado of Brazil. Crop Breed. Appl. Biotechnol. 12: 8-16. http://dx.doi. org/10.1590/S1984-70332012000100002

R Development Core Team (2012). R: a language and environment for statistical computing. R Foundation for Statistical Computing, Vienna.

Ribeiro ND, Jost E and Carnelutti Filho A (2004). Efeitos da interação genótipo x ambiente no ciclo e na coloração do tegumento dos grãos do feijoeiro comum. Bragantia 63: 373-380. http://dx.doi.org/10.1590/S0006$\underline{87052004000300007}$

Ribeiro ND, Domingues L da S, Gruhn EM, Zemolin AEM, et al. (2014). Desempenho agronômico e qualidade de cozimento de linhagens de feijão do grupo especiais. Cienc. Agron. 45: 92-100. http://dx.doi.org/10.1590/S1806$\underline{66902014000100012}$

Rocha VPC, Moda-Cirino V, Destro D, Fonseca Júnior N da S, et al. (2010). Adaptabilidade e estabilidade da característica produtividade de grãos dos grupos comerciais carioca e preto de feijão. Semin. Cienc. Agrar. 31: 39-54. http://dx.doi. org/10.5433/1679-0359.2010v31n1p39

Silva GAP, Chiorato AF, Gonçalves JGR, Perina EF, et al. (2013). Análise de adaptabilidade e estabilidade de produção em ensaios regionais de feijoeiro para o estado de São Paulo. Rev. Ceres 60: 59-65. http://dx.doi.org/10.1590/S0034737X2013000100009

Torga PP, Melo PGS, Pereira HS, de Faria LC, et al. (2013). Interaction of common beans cultivars of the black group with years, locations and sowing seasons. Euphytica 189: 239-248. http://dx.doi.org/10.1007/s10681-012-0793-y

Zobel RW, Wright MJ and Gauch HG (1988). Statistical analysis of a yield trial. Agron. J. 80: 388-393. http://dx.doi. org/10.2134/agronj1988.00021962008000030002x

Genetics and Molecular Research 15 (4): gmr15049095 